Western University

Scholarship@Western

Aboriginal Policy Research Consortium International (APRCi)

2012

\title{
Children and adolescent exposure to alcohol advertising during Bathurst 1000
}

Sondra L. Davoren

Craig A. Sinclair

Follow this and additional works at: https://ir.lib.uwo.ca/aprci

Part of the Health Communication Commons, and the Substance Abuse and Addiction Commons

Citation of this paper:

Davoren, Sondra L. and Sinclair, Craig A., "Children and adolescent exposure to alcohol advertising during Bathurst 1000" (2012). Aboriginal Policy Research Consortium International (APRCi). 252.

https://ir.lib.uwo.ca/aprci/252 


\section{Children and adolescent exposure to alcohol advertising during Bathurst 1000}

\section{Sondra L. Davoren and Craig A. Sinclair}

Cancer Prevention Centre, Cancer Council Victoria

Ordinarily, alcohol advertising on free-to-air television may be shown only during standard M (Mature), MA (Mature Audience) and AV (Adult Violence) classification periods, 8:30 pm until 5 am. ${ }^{1}$ An exemption in the Commercial Television Industry Code of Practice ('the CTICP exemption') overrides this restriction and permits alcohol advertisements during live sports broadcasts between 5 am and 8:30 pm on weekends and public holidays. ${ }^{1}$

An analysis of alcohol advertising expenditure in Australia found that almost half $(46 \%)$ the alcohol advertisements were shown on weekends and public holidays. ${ }^{2}$ Of those advertisements, $44 \%$ were shown outside the M, MA and AV classification periods during live sports broadcasts - reflecting the impact of the CTICP exemption. ${ }^{3}$

Studies suggest that under-age television viewers (aged 13-17) are equally likely to be exposed to alcohol television advertisements as young adults (aged 18-24), and that the overall level of exposure of underage television viewers to alcohol advertising is extremely high. ${ }^{3,4}$ In 2005, six of the top 50 rating programs for young people aged 13-17 and three of the top 20 rating programs for children aged 5-12, were sporting events. ${ }^{5}$ The popularity of sport in Australia particularly with children - together with alcohol sponsorship of major sporting events and the CTICP exemption, suggests that large numbers of children and young people are being exposed to alcohol marketing at times when ordinarily they would be protected.

To quantify the amount of alcohol advertising potentially seen by under-age viewers, we collected data on the amount of in-break alcohol advertising during the 2008 broadcast of the Bathurst V8 car race and analysed footage of the race to measure the time on screen of alcohol sponsorship (e.g. alcohol branding on track signage and sponsored race cars).

We found that 117,000 people aged 5-17 watched the Bathurst telecast, which is high by Australian standards (an episode of Playschool attracts around 119,000 viewers). ${ }^{1}$ In-break alcohol 
advertising started as early as 6.00 am when a large number of children and young people were watching, potentially unsupervised. Children and young people in Brisbane, for example, would have seen 11 alcohol ads by the time the race started at 10:30 am.

The race ran from 10:35 am until 5:05 pm. In a two-hour period between 3:30 and 5:30 pm, there were 106 instances of visual alcohol sponsorship, equating to just less than one per minute, and - assuming a constant level of visual alcohol sponsorship across the entire race broadcast - potentially 26 minutes $(15 \%)$ of alcohol sponsorship across the race broadcast. Including in-break alcohol advertisements, children and young people who watched the whole race were potentially exposed to 35 minutes of alcohol marketing.

Although the alcohol industry argues that it does not deliberately set out to target under-age drinkers, ${ }^{6}$ our investigation suggests that alcohol advertising during sporting broadcasts has the potential to reach a significant number of children and young people; and that this exposure is facilitated by an exemption that permits alcohol advertising before $8: 30 \mathrm{pm}$.

Alcohol advertising is known to encourage early initiation of drinking and, in the long term, higher alcohol consumption. ${ }^{7}$ Efforts to reduce young people's exposure to alcohol advertising have the potential to reduce the risk of alcohol-related chronic diseases later in life, which are related to sustained heavy drinking over a lifetime.

A key policy intervention for reducing alcohol-related harm is to limit alcohol-marketing communications. ${ }^{8}$ This was recognised in the 2009 National Preventative Health Strategy, which recommended phasing out alcohol promotions from times and placements that have high exposure to young people aged up to 25 years, including during live sport broadcasts and high adolescent/child viewing times. ${ }^{9}$

Evidence on the extent of alcohol-related harm is strong; but equally, so is the evidence for an effective preventive response. The National Preventative Health Strategy recommendations are by no means unachievable in the current environment. As a first step the CTICP exemption must be removed, followed by the phasing out of alcohol sponsorship of sporting and cultural events, particularly those with strong appeal to children and young people. The advent of the new National Preventative Health Agency is an opportunity for driving these, and other, recommendations forward.

Alcohol companies are subject to few limits on their freedom to advertise; as such, they are permitted to take a leading role in normalising alcohol use in children and young people, often under the guise of advertising to adults. To continue to allow regulatory inconsistencies such as the CTICP exemption is to prioritise the rights of the least vulnerable in our society, over the needs of the most vulnerable.

\section{References}

1. Free TV Australia. Commercials which advertise alcoholic drinks. In: 2010 Commercial Television Industry Code of Practice. Section 6.7. Mosman (AUST): Free TV Australia; 2011.

2. Lace F. Alcohol Beverage Advertising in Mainstream Australian Media 2005 to 2007: Expenditure and Exposure. Melbourne (AUST): Victorian Department of Human Services for the Monitoring of Alcohol Advertising Committee; 2009 April. p. 4.

3. Fielder L, Donovan R, Ouschan R. Exposure of children and adolescents to alcohol advertising on Australian metropolitan free-to-air television. Addiction. 2009;104(7):1157-65.

4. Winter MV, Donovan RJ, Fielder LJ. Exposure of children and adolescents to alcohol advertising on television in Australia. J Stud Alcohol Drugs. 2008;69(5):5676-83.
5. Australian Communications and Media Authority. Children's Viewing Patterns on Commercial, Free-to-air and Subscription Television: Report analysing audience and ratings data for 2001, 2005 and 2006. Melbourne (AUST): Commonwealth of Australia; 2007 May. p. 47.

6. Roche AM, Bywood PT, Borlagdan J, Lunnay B, Freeman T, Lawton L, et al. Young People and Alcohol: The Role of Cultural Influences. Adelaide (AUST): National Centre for Education and Training on Addiction; 2008. p. 133.

7. Hastings G, Brooks O, Stead M, Angus K, Anker T, Farrell T. Failure of self regulation of UK advertising. BMJ. 2010;340:5650.

8. Gilmore I. Alcohol and social marketing - Is it time to ban all forms of marketing? BMJ. 2009;339:3646.

9. National Preventative Health Taskforce. Australia: The Healthiest Country by 2020. Canberra (AUST): Commonwealth of Australia; 2009. p. 251.

Correspondence to: Ms Sondra Davoren, Cancer Prevention Centre, Cancer Council Victoria, 100 Drummond Street, Carlton, Victoria 3053; e-mail: sondra.davoren@ cancervic,org.au 